\title{
Kultura bez barier - problematyka prawna ułatwień na rzecz osób z niepełnosprawnościami narządu wzroku i słuchu
}

\author{
Maria Karcz-Kaczmarek \\ Uniwersytet Łódzki \\ mkaczmarek@wpia.uni.lodz.pl \\ ORCID: https://orcid.org/0000-0002-4786-4872
}

\section{Prawo do kultury w ujęciu krajowym i międzynarodowym}

Prawo do kultury uznawane jest obecnie za istotny element kanonu praw człowieka ${ }^{1}$. Poświadcza to sam fakt umieszczenia postanowień dotyczących udziału w życiu kulturalnym w aktach prawnych o uniwersalnym i podstawowym znaczeniu dla praw i wolności. Zgodnie z przepisem art. 27 pkt 1 Powszechnej Deklaracji Praw Człowieka ${ }^{2}$ każdy człowiek ma prawo do swobodnego uczestniczenia w życiu kulturalnym społeczeństwa, do korzystania ze sztuki, do uczestniczenia w postępie nauki i korzystania $\mathrm{z}$ jego dobrodziejstw. W literaturze wskazano, iż w tekście oryginalnym powołanego dokumentu użyto określenia community, a nie society, zatem prawo to dotyczy nie tyle udziału w życiu kulturalnym społeczeństwa, co udziału w życiu kulturalnym wspólnoty ${ }^{3}$. Prawo do udziału w życiu kulturalnym zagwarantowano także w art. 15 Międzynarodowego paktu praw gospodarczych, społecznych i kulturalnych ${ }^{4}$. Państwa-strony zobowiązały się w nim do podejmowania niezbędnych środków w celu osiągnięcia pełnej realizacji tego prawa, czyli do ochrony, rozwoju i upowszechniania nauki i kultury. Wprowadzenie do międzynarodowego po-

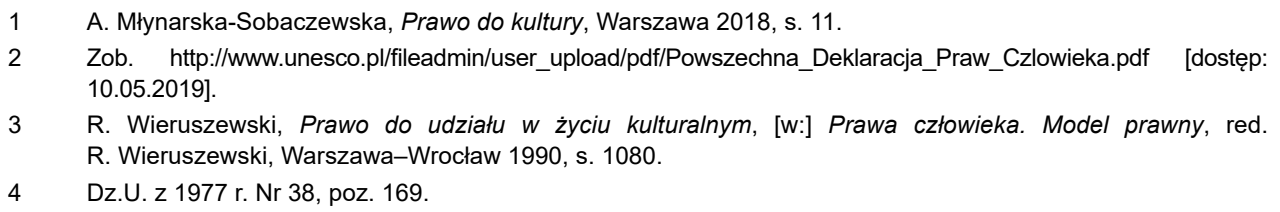


rządku prawnego prawa do kultury służy realizacji idei zapewnienia wszystkim ludziom dobrodziejstwa korzystania z dziedzictwa kulturalnego. Postanowienia te są zatem bardzo cenne $\mathrm{z}$ punktu widzenia jednostki. W praktyce pełna realizacja tego prawa okazała się jednak niemożliwa ${ }^{5}$. Jedną z przyczyn tego stanu rzeczy jest m.in. istotne zróżnicowanie kategorii odbiorców kultury. Rolą międzynarodowego, jak i krajowego prawodawcy jest zauważenie specyficznych potrzeb i ograniczeń określonych kategorii odbiorców i ułatwienie im dostępu do szeroko rozumianej kultury. A zapewnienie osobom z niepełnosprawnościami możliwości udziału w życiu kulturalnym stanowi ważny element działalności władz publicznych. Wyrazem zrozumienia tego rodzaju potrzeb społecznych była m.in. współorganizowana przez ministra kultury i dziedzictwa narodowego konferencja „Sztuka i niepełnosprawność: przekraczanie granic" (Warszawa 2019) ${ }^{6}$. Jej przedmiotem było zwiększenie dostępności oraz aktywności osób z niepełnosprawnościami w obszarze kultury i sztuki w aspekcie rozwiązań międzynarodowych oraz krajowych. Biorąc pod uwagę dane statystyczne dotyczące problematyki niepełnosprawności oraz dane demograficzne wskazujące na zwiększający się procent osób starszych w społeczeństwie ${ }^{7}$, rozszerzenie działań na rzecz zapewnienia szerokiego dostępu do kultury należy uznać za uzasadnione i oczekiwane.

Przepisy Konstytucji $\mathrm{RP}^{8}$ nie ustanawiają expressis verbis prawa do kultury na rzecz osób z niepełnosprawnościami. Przepis art. 69 stanowi o udzielaniu przez władze publiczne osobom niepełnosprawnym - zgodnie z ustawą - pomocy w zabezpieczaniu egzystencji, przysposobieniu do pracy oraz komunikacji społecznej. Wskazane postanowienie zaliczane jest w doktrynie ${ }^{9}$ i orzecznictwie $^{10}$ do wypowiedzi ustrojodawcy, które określają poziom konstytucyjnych gwarancji sprowadzających się do zobowiązania władzy publicznej do wspierania osób niepełnosprawnych. Przepis art. 69 Konstytucji RP nie stanowi źródła konstytucyjnego prawa

5 A. Młynarska-Sobaczewska, Prawo do kultury..., s. 11.

6 Konferencja odbyła się 4 kwietnia 2019 r. w Akademii Sztuk Pięknych w Warszawie. Zorganizowali ją wspólnie MKiDN, Instytut Teatralny im. Zbigniewa Raszewskiego, Instytut Muzyki i Tańca oraz British Council. Konferencja stanowiła element realizacji przez MKiDN Programu Dostępność Plus oraz wyraz międzynarodowej współpracy w ramach projektu „Europe Beyond Access”. Działania te podjęte zostały przy wsparciu finansowanego przez Unię Europejską programu Creative Europe; zob. Paweł Lewandowski: chcemy inspirować do zwiększania dostępności kultury, Ministerstwo Kultury i Dziedzictwa Narodowego, 4.04.2019, http:// mkidn.gov.pl/pages/posts/pawel-lewandowski-chcemy-inspirowac-do-zwiekszania-dostepnosci-kultury-9406. php [dostęp: 10.05.2019].

$7 \quad$ Zgodnie z informacją Ministerstwa Inwestycji i Rozwoju obecnie w Polsce żyje prawie 9 mln osób powyżej 60. roku życia. Szacuje się, iż w 2030 r. liczba ta będzie wynosić około 10,7 mln, czyli osoby powyżej 60. roku życia będą stanowić blisko 30\% ludności kraju; zob. Program Dostępność Plus, gov.pl, https://www.gov.pl/web/ archiwum-inwestycje-rozwoj/program-dostepnosc-plus [dostęp: 7.05.2019].

$8 \quad$ Dz.U. z 1997 r. Nr 78, poz. 483.

9 K. Ślebzak, Komentarz do art. 69, [w:] Konstytucja RP. Tom 1. Komentarz art. 1-86, red. M. Safjan, L. Bosek, Warszawa 2016, s. 1568-1569.

10 Por. wyrok TK z dnia 21 października 2014 r., K. 38/13, OTK-A 2014, nr 9, poz. 104; wyrok TK z dnia 20 grudnia 2012 r., K 28/11, OTK-A 2012, nr 11, poz. 137. 
Kultura bez barier - problematyka prawna ułatwień na rzecz osób...

podmiotowego, ale wyraża wytyczną dla polityki państwa w analizowanym zakre$\operatorname{sie}^{11}$. Elementem polityki wspierania osób $\mathrm{z}$ niepełnosprawnościami jest bez wątpienia zapewnianie im dostępu do kultury stanowiącej ważny element komunikacji społecznej. Udział w kulturze przyczynia się bowiem do budowania poczucia własnej tożsamości przez jednostki, jak i do kreowania wspólnoty lokalnej, narodowej i europejskiej. W myśl art. 6 ust. 1 Konstytucji RP dostęp do dóbr kultury będących źródłem tożsamości narodu polskiego, jego trwania i rozwoju winien mieć charakter powszechny i równy. O prawie osób niepełnosprawnych do pełnego uczestnictwa w życiu kulturalnym i artystycznym stanowi Karta Praw Osób Niepełnosprawnych ${ }^{12}$, przyjęta przez Sejm RP 1 sierpnia 1997 r. Deklaracja ta wskazuje na konieczność zapewnienia dostępu do dóbr i usług umożliwiających pełne uczestnictwo w życiu społecznym oraz na prawo do życia w środowisku wolnym od barier funkcjonalnych. Wskazany akt prawny nie ma charakteru powszechnie obowiązującego, stanowi jednak deklarację woli ustawodawcy do zapewnienia „niezależnego, samodzielnego i aktywnego życia osobom niepełnosprawnym”. Deklaracja ta powinna znaleźć odzwierciedlenie zarówno w kształtowaniu regulacji prawnych, jak i podejmowaniu użytecznych i oczekiwanych przez osoby z niepełnosprawnościami działań praktycznych w sferze kultury. Zapewnienie tej grupie osób pełnego dostępu do kultury można powiązać z zakazem dyskryminacji ze względu na niepełnosprawność. Zdaniem Piotra Dobosza ${ }^{13}$ przewidziany m.in. w art. 10 Traktatu o funkcjonowaniu Unii Europejskiej ${ }^{14}$ oraz w art. 21 Karty praw podstawowych ${ }^{15}$ zakaz wyraża ideę sprawiedliwość międzypokoleniowej w układzie horyzontalno-wertykalnym.

Prawo osób niepełnosprawnych do uczestniczenia w życiu kulturalnym na zasadzie równości $\mathrm{z}$ innymi osobami wyrażone zostało expressis verbis $\mathrm{w}$ art. 30 Konwencji o prawach osób niepełnosprawnych, sporządzonej w Nowym Jorku dnia 13 grudnia 2006 r. ${ }^{16} \mathrm{~W}$ myśl wskazanego postanowienia państwa-strony podejmują wszelkie odpowiednie środki w celu zapewnienia osobom niepełnosprawnym w dogodnych dla nich formach - dostępu do materiałów w dziedzinie kultury oraz do programów telewizyjnych, filmów, teatru i innego rodzaju działalności kulturalnej. Dostępność dotyczyć ma także miejsc działalności kulturalnej, takich jak teatry, muzea, kina, biblioteki i usługi turystyczne, oraz, w miarę możliwości, udostępniania zabytków i miejsc ważnych dla kultury narodowej. Konwencja o prawach osób niepełnosprawnych podkreśliła nie tylko rangę działań służących likwidacji barier

11 K. Ślebzak, Komentarz..., s. 1569.

12 M.P. z 1997 r. Nr 50, poz. 475.

13 P. Dobosz, Sprawiedliwość międzypokoleniowa w prawie administracyjnym, [w:] Sprawiedliwość i zaufanie do władz publicznych w prawie administracyjnym, red. M. Kasiński, M. Stahl, K. Wlaźlak, Warszawa 2015, s. 89-92.

14 Dz.U. z 2004 r. Nr 90, poz. 864.

15 Dz.Urz. UE C. z 2007 r. nr 303 poz. 1.

16 Dz.U. z 2012 r. poz. 1169. 
w dostępie do kultury, ale także działań służących rozwojowi i wykorzystaniu potencjału twórczego, artystycznego i intelektualnego osób niepełnosprawnych.

$\mathrm{Na}$ uwagę zasługują również postanowienia Konwencji o uznaniu szczególnej tożsamości kulturowej i językowej, w tym języków migowych i kultury osób niesłyszących. Konwencja z 2006 r. w sposób kompleksowy odniosła się zatem do problematyki osób z niepełnosprawnościami jako odbiorców i twórców kultury, których działalność służyć ma „nie tylko własnej korzyści, ale także wzbogaceniu społeczeństwa”. Od 22 stycznia 2011 r. zgodnie z decyzją Rady z dnia 26 listopada 2009 r. nr 2010/48/WE w sprawie zawarcia przez Wspólnotę Europejską Konwencji Narodów Zjednoczonych o prawach osób niepełnosprawnych Unia zobowiązana jest do przestrzegania postanowień wskazanej konwencji, której przepisy stały się integralną częścią unijnego porządku prawnego. Z kolei w Karcie praw podstawowych UE zaakcentowano prawo osób w podeszłym wieku do godnego i niezależnego życia oraz do uczestniczenia w życiu społecznym i kulturalnym (art. 25), a także prawo osób niepełnosprawnych do korzystania ze środków mających zapewnić im samodzielność, integrację społeczną i zawodową oraz udział w życiu społeczności (art. 26).

\section{Ułatwienia na rzecz osób z niepełnosprawnościami narządu wzroku na gruncie prawa polskiego}

Analizę regulacji prawnych dotyczących osób z niepełnosprawnością narządu wzroku warto poprzedzić krótkim przedstawieniem wymiaru praktycznego wskazanego zagadnienia. Raport opublikowany przez Lancet Global Health wskazuje, że na świecie żyje ok. 36 mln niewidomych, a w 2050 r. liczba ta ma się zwiększyć do $115 \mathrm{mln}$. Przewiduje się, że najwięcej osób straci wzrok w Południowej Azji oraz w Afryce Subsaharyjskiej. W Europie i USA głównym powodem wzrostu liczby osób niewidomych jest starzenie się społeczeństw ${ }^{17}$. Należy zatem stwierdzić, że zapewnienie dostępu do dóbr kultury osobom $z$ tego rodzaju niepełnosprawnościami jest istotnym zagadnieniem społecznym i prawnym. W większości państw europejskich, w tym w Polsce, prawo przewiduje ułatwiony dostęp do wytworów kultury przez osoby niewidome i niedowidzące. Mimo to szacuje się, że nie więcej niż 5\%

17 Zob. Z. Wojtasiński, Trzykrotny wzrost liczby niewidomych na świecie do 2050 r., mp.pl, 3.08.2017, https:// www.mp.pl/pacjent/okulistyka/aktualnosci/169308,trzykrotny-wzrost-liczby-niewidomych-na-swiecie-do-2050-r. [dostęp: 10.05.2019]. Z kolei Polski Związek Niewidomych zrzesza ok. 60 tys. osób; szacuje się, że osób niemogących czytać czarnego druku jest w Polsce 300 tys., http://pzn.org.pl. Według danych Głównego Urzędu Statystycznego (2004) w Polsce jest 1820300 osób niepełnosprawnych z powodu uszkodzeń i chorób narządu wzroku we wszystkich grupach wiekowych. Różnica między danymi GUS a PZN wynika z dwóch podstawowych przyczyn - nie wszystkie osoby niewidome należą do PZN oraz dane GUS obejmują osoby z niepełnosprawnością uszkodzenia i chorób narządu wzroku w każdym stopniu, również i lekkim, a takie osoby nie są przyjmowane do PZN. Por. Zbiorczy raport z diagnozy świadczonych usług z zakresu rehabilitacji społecznej dla osób niepełnosprawnych w Polsce, red. B.M. Kaczmarek, Warszawa 2011, s. 4. 
Kultura bez barier - problematyka prawna ułatwień na rzecz osób...

publikacji drukowanych na świecie jest dostępnych w formatach, z którymi osoby z dysfunkcjami narządu wzroki mogą się zapoznawać. Z danych Ministerstwa Kultury z lat 2011-2013 wynika, że w Polsce dostępność do tego typu książek wynosi jedynie między 7 a 20\%, mimo że szybko rozwijająca się technologia cyfrowa znacznie ułatwia publikowanie $\mathrm{w}$ formatach odpowiadających specyficznym potrzebom czytelników $^{18}$. Brak tego typu dedykowanej oferty wydawniczej, głównie nowości wydawniczych i dzieł naukowych, jest dotkliwy i przyczynia się do swoistego wykluczenia społecznego. Przegląd rynku wydawniczego wskazuje, że osoby cierpiące na schorzenia narządu wzroku nie mają także swobodnej i pełnej możliwości korzystania $z$ oferty prasowej. Potrzeby czytelnicze tej szczególnej grupy zaspokaja przede wszystkim przewidziana w ustawie z dnia 27 czerwca 1997 r. o bibliotekach $^{19}$ Centralna Biblioteka Niewidomych. Instytucja ta zapewnia obsługę biblioteczną niewidomych oraz koordynuje działalność pokrewnych bibliotek i instytucji. Obecnie funkcję Centralnej Biblioteki Niewidomych pełni Główna Biblioteka Pracy i Zabezpieczenia Społecznego (GBPiZS), która przejęła i rozwija działalność Biblioteki Centralnej Polskiego Związku Niewidomych w zakresie gromadzenia, udostępniania i adaptacji księgozbioru do potrzeb czytelników z dysfunkcją wzroku i innych osób niepełnosprawnych, niemogących czytać zwykłego, czarnego druku.

Księgozbiór GBPiZS - ze względu na sposób zapisu - dzieli się na: publikacje drukowane pismem Braille’a, książki mówione, zbiory tyflologiczne (wydane w zwykłym druku), filmy z audiodeskrypcją, płyty muzyczne oraz teksty cyfrowe. Trzon księgozbioru, około 50 tys. woluminów, stanowią materiały biblioteczne w piśmie Braille’a. Składają się na niego literatura piękna, powieści dla dzieci, młodzieży i dorosłych, podręczniki szkolne, słowniki, nuty, mapy, atlasy, dziewiętnastowieczne druki i manuskrypty, pozycje popularnonaukowe, poradniki, książki w językach obcych oraz bieżące i archiwalne czasopisma środowiska niewidomych i słabowidzących. Zbiór książek mówionych obejmuje nagrania w wykonaniu znakomitych lektorów i aktorów ${ }^{20}$, słuchowiska teatru polskiego radia, powieści ilustrowane muzycznie oraz niewielką liczbę nagrań dokonanych przez wolontariuszy. Zbiór ten liczy około 500 tys. kaset, 6 tys. płyt i około 7 tys. tytułów w zapisie cyfrowym. Zasoby filmów z audiodeskrypcją obejmują ok. 650 pozycji. Z kolei płyty muzyczne (zbiór muzyki klasycznej i rozrywkowej) udostępniane są wyłącznie w siedzibie biblioteki. Ponadto książnica dysponuje około 2 tys. publikacji muzycznych w zapisie cyfrowym, czyli literaturą zapisaną w sposób umożliwiający jej odczyt na monitorze brajlowskim lub mową syntetyczną. Zbiory Centralnej Biblioteki

\footnotetext{
18 Zob. K. Sobczak, Niepełnosprawni mają mieć lepszy dostęp do utworów drukowanych, Prawo.pl, 30.10.2018 https://www.prawo.pl/prawo/wdrozenie-traktatu-z-marrakeszu-w-ue-ws-utworow-drukowanych-dla,322408.html [dostęp: 10.05.2019].

19 Dz.U. z 2018 r. poz. 574.

20 Książki czytają m.in.: Ksawery Jasieński, Elżbieta Kijowska, Anna Romantowska, Leszek Teleszyński.
} 
Niewidomych są bardzo cenne i powinny by systematycznie poszerzane, na miarę potrzeb użytkowników. Podstawowym problemem jest niewielka dostępność najnowszych publikacji oraz niewystarczająca liczba zasobów w zapisach cyfrowych. Poza działalnością stricte biblioteczną wskazana instytucja podejmuje także działalność w zakresie skanowania książek na zamówienie czytelników, drukowania tekstów w języku Braille’a (na indywidualne potrzeby czytelników) oraz prowadzenia elektronicznej bibliografii zawartości czasopism środowiska niewidomych. Biblioteka GBPiZS podejmuje również działalność organizatorsko-społeczną, obejmującą m.in. prowadzenie e-mailowej listy dyskusyjnej dla bibliotekarzy zainteresowanych problematyką udostępniania zbiorów osobom niewidomym oraz listy dyskusyjnej poświęconej zagadnieniom społeczno-kulturalnym ${ }^{21}$. Ułatwienia na rzecz osób z niepełnosprawnością narządu wzroku ustanowione zostały także ustawą z dnia 23 listopada 2012 r. - Prawo pocztowe ${ }^{22}$. Akt ten określa kategorie przesyłek nadanych lub adresowanych do osób ociemniałych, zwolnionych z opłat za usługi pocztowe. Zgodnie z przepisem art. 26 tejże ustawy należą do nich przesyłki dla ociemniałych nadane przez: 1) osobę legitymującą się orzeczeniem właściwego organu orzekającego o znacznym lub umiarkowanym stopniu niepełnosprawności z tytułu uszkodzenia narządu wzroku i adresowane do biblioteki lub organizacji osób niewidomych lub ociemniałych bądź do organizacji, których celem statutowym jest działanie na rzecz osób niewidomych lub ociemniałych; 2) bibliotekę lub organizację osób niewidomych lub ociemniałych bądź organizację, których celem statutowym jest działanie na rzecz osób niewidomych lub ociemniałych, i adresowana do osoby niewidomej lub ociemniałej; 3) osobę niewidomą lub ociemniałą bądź skierowana do tej osoby zawierająca wyłącznie informacje utrwalone pismem wypukłym. Zwolnienie z opłaty za usługę pocztową ustalane jest według obowiązującego cennika usług powszechnych dla przesyłki pocztowej niebędącej przesyłką najszybszej kategorii, tego samego rodzaju, tej samej masy lub innej cechy, od której jest uzależniona wysokość opłaty.

Zwolnienie nie obejmuje opłaty za potwierdzenie odbioru przesyłki rejestrowanej. Wykaz bibliotek, organizacji osób niewidomych lub ociemniałych oraz organizacji, których celem statutowym jest działanie na rzecz osób niewidomych lub ociemniałych zawarty jest w rozporządzeniu Ministra Pracy i Polityki Społecznej oraz Ministra Kultury i Dziedzictwa Narodowego z dnia 6 września 2013 r. ${ }^{23}$ W marcu 2019 r. w Ministerstwie Rodziny, Pracy i Polityki Społecznej podjete zostały prace nad nowelizacją wskazanego rozporządzenia w celu zwiększenia licz- 
Kultura bez barier - problematyka prawna ułatwień na rzecz osób...

by podmiotów korzystających ze zwolnień przewidzianych w prawie pocztowym ${ }^{24}$. Efektem tychże prac jest zmiana rozporządzenia z 7 stycznia $2020 \mathrm{r}^{25}$ Należy stwierdzić, że ułatwienia przewidziane w analizowanych ustawach mają podstawowy charakter i na pewno warto przemyśleć ich rozszerzenie.

\section{Ułatwienia na rzecz osób z niepełnosprawnościami narządu wzroku i słuchu na gruncie prawa międzynarodowego}

W sferze uprawnień osób z niepełnosprawnościami narządu wzroku ważnym wydarzeniem było przyjęcie przez Polskę podpisanego 28 czerwca 2013 r. w Marrakeszu Traktatu Światowej Organizacji Własności Intelektualnej w sprawie ułatwienia dostępu do opublikowanych utworów drukowanych osobom niewidomym i słabowidzącym oraz osobom $\mathrm{z}$ niepełnosprawnościami uniemożliwiającymi zapoznawanie się z drukiem (traktat z Marrakeszu). W imieniu Unii Europejskiej na mocy decyzji Rady z dnia 14 kwietnia 2014 r. $^{26}$ - w negocjacjach traktatu z Marrakeszu udział brała Komisja Europejska, która podpisała dokument 30 kwietnia 2014 r. Następnie, 21 października 2014 r., Komisja Europejska przedstawiła projekt decyzji Rady w sprawie zawarcia w imieniu Unii Europejskiej traktatu z Marrakeszu. Wniosek ten nie uzyskał jednak wymaganej większości w Radzie. Część państw członkowskich, tj. Czechy, Francja, Litwa, Węgry, Rumunia, Finlandia i Zjednoczone Królestwo, kwestionowało bowiem kompetencje UE do zawarcia traktatu. Z uwagi na to Komisja Europejska przedstawiła Europejskiemu Trybunałowi Sprawiedliwości (ETS) wniosek o wydanie opinii dotyczącej charakteru kompetencji Unii w odniesieniu do tegoż traktatu i uzyskanie odpowiedzi na pytanie, czy Unia Europejska posiada wyłączne kompetencje do zawarcia traktatu z Marrakeszu $^{27}$. Jednocześnie, nie czekając na opinię ETS ${ }^{28}$, Komisja Europejska pro-

24 Zob. https://www.monitorowanieprawa.pl/opiniowane-akty-prawne/archiwalne-opiniowane-akty-prawne/812-kwiecien-2019/projekt-rozp-mrpips-oraz-mkidn-zmieniajacego-rozporzadzenie-w-sprawie-wykazu-bibliotek-organizacji-osob-niewidomych-lub-ociemnialych-oraz-organizacji.html [dostęp: 10.05.2019].

25 Dz.U. z 2020 r. poz. 77.

26 Decyzja Rady z dnia 14 kwietnia 2014 r. w sprawie podpisania, w imieniu Unii Europejskiej, Traktatu z Marrakeszu o ułatwieniu dostępu do opublikowanych utworów osobom niewidomym, słabowidzącym i osobom z niepełnosprawnościami uniemożliwiającymi zapoznawanie się z drukiem (Dz.U. UE L 2014 nr 115 poz. 1).

27 Więcej zob. K. Sztobryn, Z Marrakeszu do Brukseli, czyli w drodze do zapewnienia dostępu do utworów dla osób niewidomych, słabowidzących i z niepełnosprawnościami uniemożliwiającymi zapoznawanie się z drukiem, [w:] Experientia docet. Księga jubileuszowa ofiarowana Pani Profesor Elżbiecie Traple, red. P. Kostański, P. Podrecki, T. Targosz, Warszawa 2017. Zob. K. Sztobryn, Dostęp do utworów dla osób z niepełnosprawnościami uniemożliwiającymi zapoznawanie się z drukiem według prawa unijnego, „Europejski Przegląd Sądowy" 2018, nr 7, s. 21-25.

28 Opina ETS nr 3/15 wydana została dnia 14 lutego 2017 r. Trybunał stwierdził, że „zawarcie traktatu z Marrakeszu o ułatwieniu dostępu do opublikowanych utworów osobom niewidomym, niedowidzącym i cierpiącym na inne zaburzenia odczytu druku jest objęte kompetencją wyłączną Unii, gdy wszystkie obowiązki wynikające z tego traktatu należą do dziedziny objętej już w dużej mierze wspólnymi zasadami Unii i że zawarcie tego traktatu może mieć wpływ na te zasady lub zmienić ich zakres", http://eur-lex.europa.eu. 
wadziła prace nad implementacją traktatu z Marrakeszu. Wdrożenie do porządku UE postanowień traktatowych związane było z przyjęciem rozporządzenia Parlamentu Europejskiego i Rady (UE) 2017/1563 z dnia 13 września 2017 r. w sprawie transgranicznej wymiany między Unią a państwami trzecimi kopii w dostępnych formatach określonych utworów i innych przedmiotów chronionych prawem autorskim i prawami pokrewnymi z korzyścią dla osób niewidomych, osób słabowidzących lub osób z niepełnosprawnościami uniemożliwiającymi zapoznawanie się z drukiem ${ }^{29}$ oraz dyrektywy Parlamentu Europejskiego i Rady (UE) 2017/1564 z dnia 13 września 2017 r. w sprawie niektórych dozwolonych sposobów korzystania $\mathrm{z}$ określonych utworów i innych przedmiotów chronionych prawem autorskim i prawami pokrewnymi z korzyścią dla osób niewidomych, osób słabowidzących lub osób z niepełnosprawnościami uniemożliwiającymi zapoznawanie się z drukiem oraz w sprawie zmiany dyrektywy 2001/29/WE w sprawie harmonizacji niektórych aspektów praw autorskich i pokrewnych w społeczeństwie informacyjnym $^{30}$. Termin implementacji wskazanych aktów prawnych upłynął 11 października 2018 r.

W traktacie z Marrakeszu ustanowiono szereg przepisów międzynarodowych, które zapewniają ograniczenia lub wyjątki w zakresie prawa autorskiego na szczeblu krajowym na korzyść osób niewidomych, słabowidzących i osób z niepełnosprawnościami uniemożliwiającymi zapoznawanie się z drukiem. Traktat ułatwia także transgraniczną wymianę kopii opublikowanych utworów powstałych na mocy ograniczeń lub wyjątków w zakresie praw autorskich. Polska podpisała traktat z Marrakeszu 24 czerwca 2014 r., a jego wejście w życie nastąpiło 30 września 2016 r. Przyjęcie traktatu miało pozytywne skutki w postaci zapewnienia osobom niewidomym i słabowidzącym, a także innym niepełnosprawnym narzędzi prawnych ułatwiających korzystanie z zagranicznych wydań książek i prasy w ramach dozwolonego użytku publicznego. Traktat $z$ Marrakeszu przewiduje bowiem obowiązek ustanowienia licencji ustawowych w interesie osób niewidomych, i to także w odniesieniu do transgranicznego obrotu utworami w wersjach (formatach) dostosowanych do ich potrzeb. Bardzo szeroko określony krąg adresatów licencji umożliwia jej zastosowanie nawet do osób z dysleksją. Rozbudowany jest także katalog podmiotów uprawnionych do dostarczania osobom niewidomym utworów w odpowiednich formatach. Obejmuje on agencje rządowe, organizacje typu non- profit oraz biblioteki publiczne. Efektem przyjęcia przez RP traktatu z Marrakeszu jest zwiększenie dostępu do obcojęzycznych materiałów drukowanych, jak i niezakłócona możliwość udostępniania książek wydanych w języku polskim osobom $\mathrm{z}$ niepełnosprawnościami na całym świecie - w tym, co warto podkreślić, rodakom 
Kultura bez barier - problematyka prawna ułatwień na rzecz osób...

mieszkającym zagranicą. Prawidłowe funkcjonowanie mechanizmów udostępniania materiałów drukowanych przewidzianych przez traktat ma się przyczyniać do zwiększenia liczby wydań książek w języku polskim w formatach dostosowanych do potrzeb osób z chorobami narządu wzroku. Istotne znaczenie mają także przepisy zezwalające na transgraniczną wymianę egzemplarzy utworów w formatach dostępnych dla osób niedowidzących. Warunkiem dopuszczalności tego rodzaju wymiany jest brak wiedzy upoważnionego podmiotu (lub dostatecznych podstaw, aby przypuszczać) o możliwości ich nieuprawnionego wykorzystywania przez osoby trzecie $^{31}$.

W celu wdrożenia traktatu z Marrakeszu do polskiego porządku prawnego uchwalona została 22 listopada 2018 r. ustawa o zmianie ustawy o prawie autorskim i prawach pokrewnych oraz ustawy o ochronie baz danych ${ }^{32}$. Nowelizacja ta zapewniła rzeczywistą możliwość korzystania z ułatwień przewidzianych w traktacie $z$ Marrakeszu, m.in. w sferze transgranicznej wymiany kopii utworów i innych przedmiotów objętych prawem pokrewnym w szczególnych formatach, np. w druku alfabetem Braille’a, dużym druku, książki elektroniczne i książki mówione ze specjalną nawigacją, audiodeskrypcję i transmisje radiowe ${ }^{33}$. Beneficjentami noweli są zgodnie z art. 6 ust.1 pkt 18 ustawy z dnia 4 lutego 1994 r. o prawie autorskim i prawach pokrewnych ${ }^{34}$ osoby niewidome lub $\mathrm{z}$ dysfunkcją narządu wzroku niepoddającą się korekcji w takim stopniu, aby sprawność wzroku tej osoby stała się zasadniczo równoważna ze sprawnością wzroku osoby bez takiej dysfunkcji, i które w związku z tym nie są w stanie czytać utworów wyrażonych słowem pisanym w zasadniczo takim samym stopniu jak osoba bez takiej dysfunkcji. Znowelizowane przepisy ustawy o prawie autorskim odnoszą się także do osób z ograniczoną zdolnością postrzegania lub czytania, które w związku z tym nie są w stanie czytać utworów wyrażonych słowem pisanym w zasadniczo takim samym stopniu jak osoba bez takiej dysfunkcji, a także osób, które ze względu na inną dysfunkcję fizyczną nie są w stanie trzymać książki lub posługiwać się nią lub też skupić wzroku lub poruszać oczami w stopniu umożliwiającym normalne czytanie. Zmiany, które weszły w życie 28 grudnia 2018 r., umożliwiają beneficjentom oraz upoważnionym podmiotom $^{35}$, które $\mathrm{w}$ sposób niezarobkowy zajmują się zaspokajaniem potrzeb

31 R. Markiewicz, Ilustrowane prawo autorskie, Warszawa 2018, Lex/el.

$32 \quad$ Nowelizacja weszła w życie 28 grudnia $2018 \mathrm{r}$.

33 Zob. K. Sobczak, Niepełnosprawni mają...

34 Dz.U. z 2019 r. poz. 1231.

35 Przez „upoważniony podmiot” ustawodawca rozumie: jednostkę sektora finansów publicznych, instytucję oświatową, uczelnię lub niedziałającą w celu osiągnięcia zysku organizację prowadzącą działalność pożytku publicznego, która w ramach swoich statutowych zadań prowadzi działania na rzecz beneficjentów w zakresie edukacji, szkoleń, czytania adaptacyjnego lub dostępu do informacji. W dodawanych do ustawy o prawie autorskim i prawach pokrewnych art. 35b-35e uregulowano zasady korzystania z utworu przez upoważniony podmiot oraz przyznano ministrowi właściwemu do spraw kultury i ochrony dziedzictwa narodowego kompetencję do stwierdzania, decyzją, że określony podmiot nie jest podmiotem upoważnionym. 
osób z tego typu dysfunkcjami, powoływanie się na obowiązkowy i zharmonizowany wyjątek w prawie autorskim i prawach pokrewnych w obrębie Unii Europejskiej. Regulacje dotyczące dozwolonego użytku na rzecz beneficjentów odnoszą się także do programów komputerowych ${ }^{36}$ oraz do baz danych ${ }^{37}$.

Problematyka zapewnienia osobom z niepełnosprawnościami narządu wzroku dostępu do kultury podejmowana była w prawie międzynarodowym także przed uchwaleniem traktatu z Marakeszu. Wyrazem tego była m.in. dyrektywa Parlamentu Europejskiego i Rady 2010/13/UE z dnia 10 marca 2010 r. w sprawie koordynacji niektórych przepisów ustawowych, wykonawczych i administracyjnych państw członkowskich dotyczących świadczenia audiowizualnych usług medialnych ${ }^{38}$ (tzw. dyrektywa o audiowizualnych usługach medialnych). Zgodnie z motywem 46 wskazanej dyrektywy „Prawo osób niepełnosprawnych i osób starszych do integracji i uczestnictwa w życiu społecznym i kulturalnym Unii jest nierozłącznie związane ze świadczeniem dostępnych audiowizualnych usług medialnych. Środki pozwalające na osiągnięcie dostępności powinny obejmować między innymi język migowy, wyświetlane listy dialogowe, dźwiękową ścieżkę narracyjną oraz prostą w obsłudze nawigację". Postanowienie to stanowi wyraz przyjętej przez Unię Europejską polityki upowszechnienia praw osób niepełnosprawnych i uczynienia z nich pełnoprawnych obywateli ${ }^{39}$. Celem tej polityki jest stopniowe zapewnienie dostępności do świadczonych usług dla osób z upośledzeniami wzroku lub słuchu. Dyrektywa nałożyła na nadawców audiowizualnych usług medialnych obowiązek podjęcia działań umożliwiających odbiór rozpowszechnianych programów. Udogodnienia na rzecz osób z upośledzeniami słuchu lub wzroku polegają głównie na wprowadzeniu audiodeskrypcji oraz tłumaczeń na język migowy.

\section{Ułatwienia na rzecz osób z niepełnosprawnościami narządu wzroku i słuchu na gruncie prawa krajowego}

Postanowienia dyrektywy Parlamentu Europejskiego i Rady 2010/13/UE z dnia 10 marca 2010 r. o audiowizualnych usługach medialnych implementowane zostały w Polsce w drodze nowelizacji ustawy o radiofonii i telewizji ${ }^{40} \mathrm{z}$ dnia 25 marca 2011 r. $^{41}$ Do ustawy dodano wówczas art. 21 ust. 1a pkt 10 stanowiący, że do zadań

W odniesieniu do programów komputerowych zakres dozwolonego użytku na rzecz osób niepełnosprawnych ograniczony został do korzystania na rzecz beneficjentów.

Do takiego użytku stosowane będą odpowiednio przepisy rozdziału 3 oddziału 3a ustawy o prawie autorskim i prawach pokrewnych.

Dz.Urz.UE.L.2010.95.1.

E. Czarny-Drożdżejko, Ustawa o radiofonii i telewizji. Komentarz, Warszawa 2014, s. 260.

Ustawa z dnia 29 grudnia 1992 r. o radiofonii i telewizji (Dz.U. z 2020 r. poz. 805).

Ustawa z dnia 25 marca 2011 r. o zmianie ustawy o radiofonii i telewizji oraz niektórych innych ustaw (Dz.U. z 2011 r. Nr 85, poz. 459). 
Kultura bez barier - problematyka prawna ułatwień na rzecz osób...

publicznej radiofonii i telewizji wynikających z realizowanej przez nią misji publicznej należy w szczególności zapewnianie dostępności programów lub ich części i innych usług dla osób niepełnosprawnych z powodu dysfunkcji narządu wzroku oraz osób niepełnosprawnych z powodu dysfunkcji narządu słuchu. Nowela z $2011 \mathrm{r}$. nałożyła na nadawców programów telewizyjnych obowiązek zapewniania odpowiednich udogodnień: audiodeskrypcji, napisów dla niesłyszących oraz tłumaczeń na język migowy, tak aby co najmniej $10 \%$ kwartalnego czasu nadawania programu, z wyłączeniem reklam i telesprzedaży, posiadało takie udogodnienia. Jednocześnie ustawa stanowiła, że Krajowa Rada Radiofonii i Telewizji (KRRiTV) mogła określić niższy niż ustawowy udział w programie telewizyjnym audycji z udogodnieniami odbioru dla osób niepełnosprawnych z powodu dysfunkcji narządu wzroku oraz dysfunkcji narządu słuchu. Postanowienie to miało przeciwdziałać nakładaniu nadmiernych obowiązków na nadawców, o ile było to uzasadnione ich możliwościami technicznymi, potrzebami odbiorców, sposobem rozpowszechniania i specjalizacją programu. Na podstawie wskazanego upoważnienia KRRiTV wydała rozporządzenie z dnia 28 maja 2013 r. w sprawie niższego udziału w programie telewizyjnym audycji z udogodnieniami odbioru dla osób niepełnosprawnych z powodu dysfunkcji narządu wzroku oraz osób niepełnosprawnych z powodu dysfunkcji narządu słuchu ${ }^{42}$.

Wskazane rozporządzenie istotnie zmniejszyło kwoty ekranowe (w stosunku do wybranych programów telewizyjnych do 5\% i 1\%). Dotyczyło to nadawców telewizyjnych, którzy rozpowszechniali swój program dla niewielkiego grona odbiorców lub nadawców o niedługim dziennym czasie nadawania ${ }^{43}$. W ocenie Rzecznika Praw Obywatelskich oraz organizacji pozarządowych ${ }^{44}$ wskazany ustawowo próg udogodnień w wysokości co najmniej 10\% kwartalnego czasu nadawania programów był niewystarczający. Z uwagi na to postulowano zmianę prawa w kierunku zapewnienia dostępności dla osób z niepełnosprawnościami co najmniej 50\% programów telewizyjnych. Rzecznik Praw Obywatelskich zabiegał także o to, by uprawnienia Krajowej Rady Radiofonii i Telewizji do wyłączenia niektórych typów programów z obowiązku dostosowywania nie były zbyt szerokie ${ }^{45}$. Wskazane działania i inicja-

42 Dz.U. z 2013 r. poz. 631.

43 E. Czarny-Drożdzejko, Ustawa o radiofonii..., s. 263.

44 Są to m.in.: Polski Związek Niewidomych, Polski Związek Głuchych, Towarzystwo Pomocy Głuchoniewidomym, Fundacja Widzialni, Fundacja Instytut Rozwoju Regionalnego, Polska Fundacja Osób Słabosłyszących; zob. E. Olesiak, Ustawa o radiofonii i telewizji, Polski Związek Niewidomych, https://pzn.org.pl/ustawa-o-radiofonii-i-telewizji [dostęp: 10.05.2019].

Zdaniem RPO precyzyjne uregulowanie obowiązków nadawców programów telewizyjnych ułatwiłoby osobom ze wszystkimi rodzajami niepełnosprawności dostęp do programów na zasadzie równości, przy uwzględnieniu zasady stopniowej realizacji praw społecznych. Rzecznik podkreślał potrzebę zapewnienia dostępności osobom z niepełnosprawnościami w szczególności programów telewizyjnych o najwyższej oglądalności, emitowanych w godzinach wysokiej oglądalności, a także programów nadawanych na żywo; zob. RPO: trzeba poprawić dostęp osób z niepełnosprawnościami do telewizji, Rzecznik Praw Obywatelskich, 7.03.2018, https://www. 
tywy przyczyniły się do uchwalenia nowelizacji ustawy o radiofonii i telewizji z dnia 22 marca 2018 r. $^{46} \mathrm{~W}$ obecnym stanie prawnym nadawcy programów telewizyjnych obowiązani są do zapewniania dostępności audycji dla osób z niepełnosprawnościami narządu wzroku i narządu słuchu, tak aby co najmniej 50\% kwartalnego czasu nadawania programu, $\mathrm{z}$ wyłączeniem reklam i telesprzedaży, posiadało udogodnienia. Ponadto nadawcy są obowiązani do informowania odbiorców o terminie, czasie emisji i czasie trwania audycji zawierającej udogodnienia dla osób z niepełnosprawnościami oraz o rodzaju udogodnień. W literaturze przedmiotu podkreślono, że przewidziany ustawowo procent (10\%, a obecnie $50 \%$ ) kwartalnego czasu nadawania programu telewizyjnego odnosił się łącznie do audiodeskrypcji, napisów dla niesłyszących oraz tłumaczeń na język migowy, a nie do każdej z tychże z osob$\mathrm{na}^{47}$. Odmienne stanowisko w tej kwestii prezentuje rzecznik praw obywatelskich ${ }^{48}$. Nowelizacja z 2018 r. rozszerzyła zakres upoważnienia na rzecz KRRiTV, zmieniając jednocześnie dotychczasowy punkt ciężkości z możliwości określenia niższego udziału w programie telewizyjnym audycji z udogodnieniami na rzecz wskazania w pierwszej kolejności rodzajów udogodnień dla osób niepełnosprawnych oraz udziału poszczególnych rodzajów udogodnień w łącznym czasie nadawania.

Do kompetencji KRRiTV należy także określenie rodzajów programów, w których nadawcy nie są obowiązani do wprowadzania udogodnień dla osób niepełnosprawnych. Szczegółowo kwestie te reguluje rozporządzenie KRRiT z dnia 15 listopada 2018 r. w sprawie udogodnień dla osób niepełnosprawnych z powodu dysfunkcji narządu wzroku i osób niepełnosprawnych z powodu dysfunkcji narządu słuchu w programach telewizyjnych ${ }^{49}$. Rozporządzenie wprowadziło następujące rodzaje udogodnień: audiodeskrypcję, napisy dla niesłyszących oraz tłumaczenie na język migowy. Audiodeskrypcja - na gruncie rozporządzenia - rozumiana jest jako werbalny opis treści wizualnych, umieszczony w audycji lub rozpowszechniany równocześnie $\mathrm{z}$ audycją ${ }^{50}$. Pożądany przy dokonywaniu auduodeskrypcji byłby po-

rpo.gov.pl/pl/content/rpo-trzeba-poprawi\%C4\%87-dost\%C4\%99p-os\%C3\%B3b-z-niepe\%C5\%82nosprawno\%C5\%9Bciami-do-telewizji [dostęp: 10.05.2019].

Dz.U. z 2018 r. poz. 915. Nowela weszła w życie 1 stycznia 2019 r.

47 E. Czarny-Drożdzejko, Ustawa o radiofonii..., s. 262; P. Ślęzak, Audiodeskrypcja w sferze audiowizualnejzagadnienia prawne, [w:] Rozprawy cywilistyczne. Księga pamiątkowa dedykowana Edwardowi Drozdowi, red. M. Pecyna et al., Warszawa 2013, s. 815; K. Wojciechowski, Ustawa o radiofonii i telewizji. Komentarz, Warszawa 2014, s. 234.

48 W ocenie RPO tego rodzaju interpretacja jest najmniej korzystna dla osób z niepełnosprawnościami, niezbędne jest rozważenie nowelizacji ustawy tak, aby precyzyjnie określić obowiązki nadawców telewizyjnych w zakresie zapewnienia dostępności programów dla osób z różnymi niepełnosprawnościami. Znowelizowana regulacja powinna uwzględniać odrębnie zarówno potrzeby osób z niepełnosprawnością wzroku, jak i z niepełnosprawnością słuchu; zob. Pismo RPO do KRRiTV z dnia 7 marca 2017, nr XI.815.5.2017.AK, https:// www.rpo.gov.pl/sites/default/files/RPO\%20do\%20KRRiT\%207.03.2017.pdf [dostęp: 10.05.2019].

49 Dz.U. z 2018 r. poz. 2261.

50 W literaturze prawniczej audiodeskrypcja definiowana jest w sposób bardzo zbliżony jako „werbalny opis treści audiowizualnych przekazywanych osobom niewidzącym albo słabo widzącym. Jest ona stosowana przede 
Kultura bez barier - problematyka prawna ułatwień na rzecz osób...

dział na niewidomych i słabowidzących oraz podział na niewidomych od urodzenia i ociemniałych. Osoby te bowiem odmiennie pojmują świat obrazów i kolorów, cechują się także odmienną wyobraźnią przestrzenną, umiejętnością odczytywania języka filmu czy teatru oraz rozumieniem zabiegów formalnych wpisanych w wizualne i audiowizualne treści dzieła sztuki ${ }^{51}$. W rzeczywistości jednak uwzględnienie tego postulatu jest niemożliwe, dlatego powstaje jedna, wspólna wersja werbalnego opisu, stanowiąca kompromis pomiędzy potrzebami poszczególnych grup odbiorców.

Ustawowy obowiązek zapewniania udogodnień dla osób niepełnosprawnych związany jest $\mathrm{z}$ dokonywaniem opracowań treści audiowizualnych w postaci audiodeskrypcji i rozporządzania nimi. W literaturze stwierdzono, że postanowienia art. 18 a ust. 1 oraz art. 21 ust. 1a pkt 10 ustawy o radiofonii i telewizji są regulacjami o charakterze administracyjnym i nie odnoszą się do jakiejkolwiek instytucji uprawniającej nadawcę lub producenta audiowizualnego do dokonywania opracowań treści audiowizualnych w postaci audiodeskrypcji. Zdaniem Piotra F. Piesiewicza przepisy te nie udzielają podmiotom prawa do rozporządzania i korzystania $\mathrm{z}$ audiodeskrypcji, a jedynie nakładają określone obowiązki o charakterze administracyjnym, związane z dostępnością programów dla osób niepełnosprawnych ${ }^{52}$. Natomiast $z$ uwagi na rozwiązania prawa międzynarodowego oraz gwarancje zapisane $\mathrm{w}$ instytucjach prawa UE producent utworu audiowizualnego jest $\mathrm{z}$ mocy prawa uprawniony do dokonywania opracowań utworu audiowizualnego w formie audiodeskrypcji. Brak wskazanej możliwości stanowiłby bowiem dyskryminację osób dotkniętych niepełnosprawnością narządu wzroku. Podstawę tego domniemania stanowi art. 70 ust. 1 ustawy o prawie autorskim i prawach pokrewnych (u.p.a.p.p.), zgodnie z którym producent utworu audiowizualnego nabywa na mocy umowy o stworzenie utworu albo umowy o wykorzystanie już istniejącego utworu wyłączne prawa majątkowe do eksploatacji tych utworów w ramach utworu audiowizualnego jako całości ${ }^{53}$.

Ułatwieniem dla osób z dysfunkcjami narządu słuchu są także napisy dla niesłyszących, rozumiane jako widoczny na ekranie tekst będący odpowiednikiem dialogów i narracji, korespondujący z widocznym na ekranie obrazem, zawierający rozróżnienie osób występujących w dialogu kolorami czcionki lub przy pomocy identyfikatorów tekstowych oraz opisy tekstowe efektów dźwiękowych i tła

wszystkim w celu ułatwienia osobom z dysfunkcją narządu wzroku odbioru treści, które u osób niedotkniętych taką dysfunkcją podlegają percepcji wzrokowej”. Zob. P. Ślęzak, Audiodeskrypcja w sferze..., s. 811.

52 P.F. Piesiewicz, Audiodeskrypcja jako forma realizacji przez producenta utworu audiowizualnego prawa do udziału w życiu kulturalnym przez osoby z dysfunkcją wzroku, „Europejski Przegląd Sądowy” 2018, nr 10, s. 29.

53 Wskazane zagadnienia z uwagi na cywilistyczny charakter wykraczają poza ramy niniejszego opracowania. 
dźwiękowego. Zgodnie z rozporządzeniem KRRiTV z 2018 r. napisy dla niesłyszących mogą przybierać postać widocznego na ekranie tekstu w języku polskim, zawierającego dialogi i narrację audycji obcojęzycznych (tekst zaliczany jest do czasu emisji audycji z udogodnieniami dla osób niepełnosprawnych ze współczynnikiem zmniejszającym 0,7), lub tekstu w audycjach na żywo, będącego odzwierciedleniem dialogów lub wypowiedzi, który pojawia się na ekranie z nieznacznym przesunięciem czasowym. Kolejnym rodzajem udogodnień jest tłumaczenie na język migowy dokonane przez tłumacza języka migowego - w rozumieniu ustawy z dnia 19 sierpnia 2011 r. o języku migowym i innych środkach komunikowania się ${ }^{54}$. Powołana ustawa przez polski język migowy (PJM) rozumie naturalny wizualno-przestrzenny język komunikowania się osób uprawnionych, czyli osób doświadczających trwale lub okresowo trudności w komunikowaniu się. Język migowy należy odróżnić od systemu językowo-migowego (języka miganego SJM), który został stworzony, aby ludziom słyszącym umożliwić kontakt z ludźmi głuchymi, i który jest odwzorowaniem języka polskiego. W systemie językowo-migowym znaki migowe wspierają wypowiedź dźwiękowo-artykulacyjną. Zgodnie z ustawą o języku migowym podstawowym środkiem komunikowania się osób uprawnionych jest tzw. SKOGN, czyli sposób komunikowania się osób głuchoniewidomych. W tym przypadku sposób przekazu komunikatu jest dostosowany do potrzeb wynikających z łącznego występowania dysfunkcji narządu wzroku i słuchu. W Polsce funkcjonują zatem różne systemy komunikacji migowej: polski język migowy (PJM) i system językowo-migowy (SJM) oraz sposób komunikowania się osób głuchoniemych (SKOGN). Dobrze wykwalifikowany tłumacz języka migowego posługuje się zarówno PJM, jak i SJM, elastycznie dostosowując się do możliwości osoby niesłyszącej ${ }^{55}$. Biorąc jednak pod uwagę przepisy rozporządzenia KRRiTV z 2018 r., należy podkreślić, iż nadawcy mają obowiązek tłumaczenia audycji na język migowy, a nie język migany (SJM). Szczegółowe kwestie dotyczące zakresu oraz zasad funkcjonowania rejestru tłumaczy polskiego języka migowego, systemu językowo-migowego i sposobu komunikowania się osób głuchoniewidomych reguluje rozporządzenie Ministra Pracy i Polityki Społecznej z dnia 1 czerwca 2012 r. $^{56}$

Nałożenie na nadawców administracyjnoprawnych obowiązków zapewniania w ustawowo określonym zakresie - ułatwień na rzecz osób z dysfunkcjami narządu wzroku i słuchu wpisuje się w realizację zasady niedyskryminacji z uwagi na niepełnosprawność $\mathrm{w}$ sferze prawa do kultury. $Z$ punktu widzenia dostawców usług medialnych stanowić to może jednak dodatkowe obciążenie finansowe oraz organizacyjne

\footnotetext{
54 Dz.U. z 2017 r. poz. 1824.

55 J. Staszczyk, Język migowy w administracji, „Przegląd Prawa Publicznego” 2017, nr 4, s. 61; zob. P. Kowalska, T. Durko, Język migowy jako środek komunikacji społecznej osób głuchych, „Otorynolaryngologia” 2011, nr 10(2), s. 62-64. 
Kultura bez barier - problematyka prawna ułatwień na rzecz osób...

(np. koszt zapewnienia usługi tłumacza języka migowego). Z uwagi na to obowiązujące przepisy w dalszym ciągu umożliwiają niższy niż określony w art. 18a ust. 1 ustawy o radiofonii i telewizji udział w programie telewizyjnym audycji zawierających omawiane udogodnienia, jeżeli uzasadnia to liczba mieszkańców w zasięgu programu oraz potrzeby odbiorców i możliwości nadawców. Ponadto nadawcy programów rozpowszechnianych wyłącznie w sieciach telekomunikacyjnych innych niż wykorzystywane do rozpowszechniania rozsiewczego naziemnego lub rozsiewczego satelitarnego, których zasięg ludnościowy nie przekracza 500 tys. mieszkańców, nie są obowiązani do wprowadzania udogodnień dla osób niepełnosprawnych z powodu dysfunkcji narządu wzroku i narządu słuchu ${ }^{57}$. Przepisy przewidują także możliwość dofinansowania kosztów szkolenia polskiego języka migowego z Państwowego Funduszu Rehabilitacji Osób Niepełnosprawnych, co umożliwia późniejszy wpis do rejestru tłumaczy PJM i podjęcie działalności zawodowej u nadawcy programów telewizyjnych. Katalog podmiotów uprawnionych do tego rodzaju dofinansowania jest bardzo wąski i dotyczy samej osoby uprawnionej, członka jej rodziny oraz osoby mającej stały lub bezpośredni kontakt $z$ osobą uprawnioną ${ }^{58}$. Analizując kierunek zmian przepisów ustawy o radiofonii i telewizji, należy stwierdzić, że zwiększanie kwartalnego czasu nadawania programu w formatach dostępnych dla osób $\mathrm{z}$ niepełnosprawnościami, a także wprowadzanie nowych rodzajów udogodnień będących rezultatem rozwoju technik przekazu jest w pełni uzasadnione i społecnie korzystne. Dzięki temu osoby z niepełnosprawnościami mogą w coraz szerszym zakresie korzystać z oferty programowej i tym samym uczestniczyć w bieżących sprawach społecznych, politycznych i kulturalnych.

\section{Działalność społeczno-organizatorska na rzecz osób z niepełnosprawnościami narządu wzroku lub słuchu}

Podstawą działalności społeczno-organizatorskiej jest ustawa z dnia 25 października 1991 r. o organizowaniu i prowadzeniu działalności kulturalnej59 ${ }^{59}$ zodnie z którą prowadzenie działalności kulturalnej jest zadaniem własnym jednostek samorządu terytorialnego (JST) o charakterze obowiązkowym (w art. 9 ust. 2). Podejmowanie działań mających na celu zapewnienie dostępności kultury wskazanym kategoriom odbiorców może także przybierać postać różnego rodzaju działań społeczno-organizatorskich, podejmowanych na podstawie ogólnych norm kom-

\footnotetext{
57 Zob. § 10 rozporządzenia KRRiTV z 2018 r.

58 Rozporządzenie Ministra Pracy i Polityki Społecznej z dnia 12 czerwca 2012 r. w sprawie dofinansowania kosztów szkolenia polskiego języka migowego, systemu językowo-migowego, sposobu komunikowania się osób głuchoniewidomych oraz tłumacza-przewodnika (Dz.U. z 2012 r. poz. 687).

Zob. tekst jedn. Dz.U. z 2020 r. poz. 194.
} 
petencyjnych $^{60}$. Do norm tego rodzaju należą m.in. przepisy tzw. ustaw samorządowych, stanowiące o zaspokajaniu zbiorowych potrzeb wspólnoty terytorialnej w zakresie kultury, w tym o zapewnianiu działalności bibliotek publicznych i innych instytucji kultury61. Działania skierowane do osób z niepełnosprawnościami z uwagi na dysfunkcje narządu wzroku lub słuchu podejmowane powinny być przede wszystkim przez samorząd terytorialny, bowiem to na jednostkach zdecentralizowanych, zgodnie z postanowieniem art. 16 ust. 2 oraz art. 163 Konstytucji RP, ciąży odpowiedzialność za wykonywanie istotnej części zadań publicznych. Działania samorządowe często mają charakter partycypacyjny - przykładem może być Sieć Dialogu, powołana przez Polski Związek Niewidomych oraz Stowarzyszenie Gmin i Powiatów Małopolski. Sieć stanowi nieformalne zrzeszenie pracowników samorządowych oraz przedstawicieli fundacji i stowarzyszeń działających na rzecz osób niewidomych i słabowidzących z terenu całej Polski. Celem sieci jest wzmocnienie potencjału uczestników, prowadzenie dialogu obywatelskiego oraz wspólne poszukiwanie rozwiązań mających na celu ułatwianie osobom niewidomym i słabowidzącym udziału w przestrzeni publicznej ${ }^{62}$. Do kategorii działań społeczno-organizatorskich podejmowanych przez JST należy też organizowanie przedsięwzięć kulturalnych, dedykowanych osobom z niepełnosprawnościami jako twórcom kultury, tj. festiwali, warsztatów, wystaw, prezentacji, promocji osiągnięć artystycznych osób z niepełnosprawnościami w mediach i placówkach kulturalnych. Istotne znaczenie ma przy tym niwelowanie barier architektonicznych i informacyjnych w obiektach kultury poprzez umieszczanie oznaczeń w języku Braille’a. Przykładem aktywności samorządu w analizowanym zakresie jest działalność podjęta m.in. przez Miasto Poznań. Raport z działań podjętych na rzecz osób $z$ niepetnosprawnościami w mieście Poznań $w 2016 r{ }^{63}$ wskazuje, że likwidacja barier i ułatwienia w sferze kultury polegają m.in. na zainstalowaniu systemu nawigacji złożonego z aktywatorów odtwarzających dźwięki w jakości MP3, z możliwością cyfrowej kontroli głośności podczas odtwarzania, i posiadających sygnalizację wibracyjną i dźwiękową instalacji systemu ułatwiającego dostęp do budynku (czujniki, dzwonek), zamieszczaniu planów tyflograficznych z udźwiękowieniem (opisy w alfabecie Braille’a, przyciski aktywujące informację audio). Realnym ułatwie-

60 Prawo administracyjne. Pojęcia, instytucje, zasady w teorii i orzecznictwie, wyd. 2, red. M. Stahl, Warszawa 2002, s. 384-385.

61 Por. art. 7 ust. 1 pkt 9 ustawy z dnia 8 marca 1990 r. o samorządzie gminnym (tekst jedn. Dz.U.z 2020 r. poz. 713); por. art. 4 ust. 1 pkt 7 ustawy z dnia 5 czerwca 1998 r. o samorządzie powiatowym (tekst jedn. Dz.U. z 2020 r. poz. 920); por. art. 14 ust. 1 pkt 3 ustawy z dnia 5 czerwca 1998 r. o samorządzie województwa (tekst jedn. Dz.U. z 2019 r. poz. 512).

62 Osoby niewidome i słabowidzące liderami komunikacji społecznej. Poradnik dla jednostek samorządu terytorialnego, red. A. Góral et al., Warszawa 2013, s. 33-34, http://www.sgpm.krakow.pl/aaksiazki/pdf/2013-12-31-osoby-niewidome-i-slabowidzace-liderami-komunikacji-spolecznej.pdf [dostęp: 8.04.2019]. Poznań, 7.07.2017, https://www.poznan.pl/mim/hc/news/raport-z-dzialan-podjetych-na-rzecz-osob-z-niepelnosprawnosciami-w-miescie-poznan-w-2016-roku,107903.html [dostęp: 8.04.2019]. 
Kultura bez barier - problematyka prawna ułatwień na rzecz osób...

niem jest zamontowanie pętli indukcyjnych w ladach bibliotecznych i w miejscach obsługi czytelników i użytkowników, które gwarantują przeprowadzenie wyraźnej i zrozumiałej rozmowy, redukującej dźwięki z otoczenia, co ułatwia komunikację osobom niedosłyszącym. Pomocne są także pasy oznaczające początek i koniec schodów oraz faktury ostrzegawcze zamontowane na posadzce, ułatwiające zwiedzanie osobom niewidomym i słabowidzącym. Korzystne jest tworzenie w bibliotekach publicznych stanowisk komputerowych dla osób niewidomych i niedowidzących, wyposażonych w specjalistyczny sprzęt i oprogramowanie, m.in. program udźwiękawiająco-ubrajlawiający, program powiększający, syntezator mowy, aplikację przeznaczoną do rozpoznawania pisma, autolektor (urządzenie skanujące tekst drukowany i przetwarzające na mowę syntetyczną), monitor brajlowski, powiększoną mysz komputerową, monitor graficzny dla niewidomych, drukarkę brajlowską, program tłumaczący dokumenty do drukarek brajlowskich, powiększalnik z możliwością podłączenia do komputera, lupę przenośną oraz tzw. czytaki (urządzenia do odsłuchu książek mówionych), z możliwością wypożyczenia przez czytelników.

Współcześnie podmioty spoza struktury administracji publicznej aktywnie włączają się w świadczenie usług na rzecz osób niepełnosprawnych. Działania podmiotów prywatnych uzupełniają, a w pewnych przypadkach stanowią nawet swoistą awangardę w stosunku do działań publicznych. Przykładem może być na przykład utworzony przez prywatną fundację we współdziałaniu z podmiotami publicznymi pierwszy w Polsce i Europie bezpłatny portal filmowy VOD ADAPTER dla osób niewidomych i niesłyszących ${ }^{64}$. Z kolei przewodnik po historii, kulturze i zabytkach Kujaw i Pomorza, dostosowany do potrzeb osób z dysfunkcją wzroku, doskonale wypełnia lukę rynku wydawniczego w tym zakresie. Publikacja ta została przygotowana w dwóch wersjach: czarnodrukowej - dla osób słabowidzących oraz brajlowskiej - dla osób niewidomych. Wersja brajlowska wzbogacona została o 10 tyflografik (grafik wypukłych), które przy zastosowaniu skali i proporcji graficznie odwzorowują m.in. gmachy Filharmonii Pomorskiej i Opery Nova, plan gotyckiej katedry w Chełmży, Muzeum Archeologiczne w Biskupinie, Krzywą Wieżę w Toruniu, toruński pomnik Mikołaja Kopernika. Zasadnicza cześć nakładu albumu wyczerpała się bardzo szybko, co świadczy o trafności tejże inicjatywy oraz dużych potrzebach w sferze publikacji skierowanych do odbiorców cierpiących na dysfunkcje narządu wzroku 65 .

\footnotetext{
64 Więcej o projekcie Adapter na stronie: www.adapter.pl [dostęp: 10.04.2019].

65 Więcej w: Rozmowa z Eweliną Czerwińską z bydgoskiego biura Fundacji Szansa dla Niewidomych, Portal Województwa Kujawsko-Pomorskiego, https://kujawsko-pomorskie.pl/biuro-prasowe-kontakt/wywiadytygodnia/27478-tyflografiki-w-tyfloprzewodniku [dostęp: 10.06.2019].
} 


\section{Zakończenie}

Zagadnienie tzw. kultury bez barier, czyli dążenie do zapewnienia równego dostępu do kultury osobom cierpiącym na schorzenia narządów wzroku i słuchu, ma charakter uniwersalny. We współczesnych państwach przeciwdziałanie jakimkolwiek dyskryminacjom i wykluczeniom społecznym nabiera coraz większego znaczenia i tematyka ta przebija się jako jedna z podstawowych kwestii społecznych. Dotyczy to również kultury, która powinna być dostępna dla wszystkich i stanowić dogodną platformę wymiany doświadczeń i poglądów. Podejmowane działania powinny być kierowane do osób z niepełnosprawnościami zarówno jako odbiorców, jak i twórców kultury. Problematyka ta podejmowana jest w prawie zarówno na poziomie krajowym, jak i międzynarodowym, w tym w prawodawstwie UE. Analizowane zagdnienia stanowią asumpt do szerszych rozważań dotyczących partycypacji osób z niepełnosprawnośiami w życiu społecznym. Działania na rzecz osób niepełnosprawnych - w miarę możliwości - winny integrować wspólnotę, a nie pogłębiać istniejące podziały na kulturę ogólnie dostępną oraz skierowaną wyłącznie do określonych grup. Stwierdzenie to nie stoi w sprzeczności z działaniami mającymi na celu kreowanie i umacnianie tożsamości kulturalnej osób z niepełnosprawnościami, tego rodzaju przedsięwzięcia mają bowiem istotne znaczenie dla poczucia przynależności do wspólnoty i mogą stanowić wręcz działania o charakterze quasi-terapeutycznym. Podejmowane - w coraz szerszym zakresie - działania podmiotów publicznych na rzecz osób z niepełnosprawnościami narządu wzroku lub słuchu stanowią realizację obowiązku zagwarantowania dostępu do kultury grupom mniejszościowym, w tym osobom mającym ograniczone możliwości percepcji. Aktywność ta stanowi nie tylko realizację zobowiązań międzynarodowych, ale przyczynia się do rozwoju kulturalnego państwa oraz budowania społeczeństwa otwartego, pozbawionego barier i uprzedzeń społecznych. Działania władz publicznych mają także na celu zaznajomienie społeczeństwa $\mathrm{z}$ wagą problematyki niepełnosprawności, tak by zagadnienia te stały się elementem dyskusji i życia społeczno-kulturalnego.

\section{Literatura}

Czarny-Drożdżejko E., Ustawa o radiofonii i telewizji. Komentarz, Warszawa 2014.

Dobosz P., Sprawiedliwość międzypokoleniowa w prawie administracyjnym, [w:] Sprawiedliwość $i$ zaufanie do władz publicznych w prawie administracyjnym, red. M. Kasiński, M. Stahl, K. Wlaźlak, Warszawa 2015.

Kowalska P., Durko T., Jezyk migowy jako środek komunikacji społecznej osób głuchych, „Otorynolaryngologia" 2011, $\mathrm{nr}$ 10(2).

Markiewicz R., Ilustrowane prawo autorskie, Warszawa 2018.

Młynarska-Sobaczewska A., Prawo do kultury, Warszawa 2018. 
Kultura bez barier - problematyka prawna ułatwień na rzecz osób...

Osobyniewidome isłabowidzace liderami komunikacjispołecznej. Poradnik dlajednosteksamorządu terytorialnego, red. A. Góral et al., Warszawa 2013.

Piesiewicz P.F., Audiodeskrypcja jako forma realizacji przez producenta utworu audiowizualnego prawa do udziału $w$ życiu kulturalnym przez osoby $z$ dysfunkcja wzroku, „Europejski Przegląd Sądowy” 2018, nr 10.

Prawo administracyjne. Pojęcia, instytucje, zasady $w$ teorii i orzecznictwie, red. M. Stahl, wyd. 2, Warszawa 2002.

Staszczyk J., Język migowy w administracji, „Przegląd Prawa Publicznego” 2017, nr 4.

Sztobryn K., Z Marrakeszu do Brukseli, czyli w drodze do zapewnienia dostępu do utworów dla osób niewidomych, słabowidzących i z niepełnosprawnościami uniemożliwiajacymi zapoznawanie się z drukiem, [w:] Experientia docet. Ksiega jubileuszowa ofiarowana Pani Profesor Elżbiecie Traple, red. P. Kostański, P. Podrecki, T. Targosz, Warszawa 2017.

Sztobryn K., Dostęp do utworów dla osób z niepełnosprawnościami uniemożliwiającymi zapoznawanie się z drukiem według prawa unijnego, „Europejski Przegląd Sądowy” 2018, nr 7.

Ślebzak K., Komentarz do art. 69, [w:] Konstytucja RP. Tom 1. Komentarz art. 1-86, red. M. Safjan, L. Bosek, Warszawa 2016.

Ślęzak P., Audiodeskrypcja w sferze audiowizualnej - zagadnienia prawne, [w:] Rozprawy cywilistyczne. Ksiega pamiątkowa dedykowana Edwardowi Drozdowi, red. M. Pecyna et al., Warszawa 2013.

Wieruszewski R., Prawo do udziału w życiu kulturalnym, [w:] Prawa człowieka. Model praw$n y$, red. R. Wieruszewski, Warszawa-Wrocław 1990.

Wojciechowski K., Ustawa o radiofonii i telewizji. Komentarz, Warszawa 2014.

Zbiorczy raport $z$ diagnozy świadczonych usług z zakresu rehabilitacji społecznej dla osób niepetnosprawnych $w$ Polsce, red. B.M. Kaczmarek, Warszawa 2011.

\section{Źródła internetowe}

Główna Biblioteka Pracy i Zabezpieczenia Społecznego, https://www.gbpizs.gov.pl.

Olesiak E., Ustawa o radiofonii i telewizji, Polski Związek Niewidomych, https://pzn.org.pl/ ustawa-o-radiofonii-i-telewizji.

Osoby niewidome i słabowidzace liderami komunikacji społecznej. Poradnik dla jednostek samorządu terytorialnego, red. A. Góral et al., Warszawa 2013, http://www. sgpm.krakow.pl/aaksiazki/pdf/2013-12-31-osoby-niewidome-i-slabowidzace-liderami-komunikacji-spolecznej.pdf.

Paweł Lewandowski: chcemy inspirować do zwiększania dostępności kultury, Ministerstwo Kultury i Dziedzictwa Narodowego, 4.04.2019, http://mkidn.gov.pl/pages/posts/pawel-lewandowski-chcemy-inspirowac-do-zwiekszania-dostepnosci-kultury-9406.php.

Pismo RPO do KRRiTV z dnia 7 marca 2017, nr XI.815.5.2017.AK, https://www.rpo.gov.pl/ sites/default/files/RPO\%20do\%20KRRiT\%207.03.2017.pdf. 
Program Dostępność Plus, gov.pl, https://www.gov.pl/web/archiwum-inwestycje-rozwoj/ program-dostepnosc-plus.

Projekt Adapter, www.adapter.pl.

Raport $z$ działań podjętych na rzecz osób z niepełnosprawnościami w mieście Poznań w 2016 roku, Poznań, 7.07.2017, https://www.poznan.pl/mim/hc/news/raport-z-dzialan-podjetych-na-rzecz-osob-z-niepelnosprawnosciami-w-miescie-poznan-w-2016-roku,107903.html.

RPO: trzeba poprawić dostęp osób z niepetnosprawnościami do telewizji, Rzecznik Praw Obywatelskich, 7.03.2018, https://www.rpo.gov.pl/pl/content/rpo-trzeba-poprawi\%C4\%87-dost\%C4\%99p-os\%C3\%B3b-z-niepe\%C5\%82nosprawno\%C5\%9Bciami-do-telewizji.

Rozmowa z Eweliną Czerwińską z bydgoskiego biura Fundacji Szansa dla Niewidomych, Portal Województwa Kujawsko-Pomorskiego, https://kujawsko-pomorskie.pl/biuro-prasowe-kontakt/wywiady-tygodnia/27478-tyflografiki-w-tyfloprzewodniku.

Sobczak K., Niepełnosprawni mają mieć lepszy dostęp do utworów drukowanych, Prawo.pl, 30.10.2018, https://www.prawo.pl/prawo/wdrozenie-traktatu-z-marrakeszu-w-ue-ws-utworow-drukowanych-dla,322408.html.

Wojtasiński Z., Trzykrotny wzrost liczby niewidomych na świecie do 2050 r., mp.pl, 3.08.2017, https://www.mp.pl/pacjent/okulistyka/aktualnosci/169308,trzykrotny-wzrost-liczby-niewidomych-na-swiecie-do-2050-r. 